\title{
Nematode Density and Biomass in an Annual Grassland Ecosystem
}

\author{
DIANA W. FRECKMAN, DON A. DUNCAN, AND JEANNE R. LARSON
}

\begin{abstract}
The nematode community structure was examined in grazed and ungrazed annual-plant rangeland on the US/IBP Grassland Biome San Joaquin Site located in the foothill-grasslands of central California. Nematode numbers and biomass were estimated from early growth to mature stages of the annual-plant vegetation. Nematode density was greater on the grazed area, predominately forbs, than on the ungrazed, mainly grass, area. A lower than normal precipitation appeared to be a limiting factor of nematode population density. The nematode trophic structure differed between the two sites, fungivores and microbivores predominating on the grazed and ungrazed sites, respectively. Indications are that the critical factors controlling nematode density and community structure on this annual grassland are not grazing but soil moisture and temperature.
\end{abstract}

Yuen (1966), Schmitt and Norton (1972), Schmitt (1973), Stanton (1974), Yeates (1974), and Smolik and Rogers (1976) have studied the function of nematodes in belowground grassland ecosystems; however, knowledge of nematodes from the California annual grassland ecosystem is almost nonexistent. Recent investigations in the mixed-grass prairie of South Dakota (Smolik 1974) provided evidence that nematodes constituted a significant pathway of energy flow, and that the application of nematicides significantly reduced nematode populations resulting in large increases in herbage production. Also, phytophagic nematode biomass was significantly higher in an ungrazed pasture than in a grazed pasture. A preliminary study in the shrub-steppe area of south-central Washington (Smolik and Rogers 1976) revealed large numbers of soil-dwelling nematodes but no consistent differences in nematode density or biomass between grazed, ungrazed, and burned areas.

In 1972, the annual grassland site of the United States International Biological Program (US/IBP), Grassland Biome, was established at the U.S. Forest Service's San Joaquin Experimental Range, $40 \mathrm{~km}$ northeast of Fresno, California. For a 3-year period, data were collected on abiotic, producer, consumer, and decomposer components of the ecosystem (Duncan 1975). A preliminary soil sampling program was undertaken in 1974 to estimate the importance of nematodes at the San. Joaquin site. Soil samples were taken on two dates (March 13 and May 1, 1974) in the grazed and ungrazed

Authors are assistant research nematologist, Department of Nematology, University of California. Riverside; research range scientist and range conservationist, Pacific Southwest Forest and Range Experiment Station, Forest Service, U.S. Department of Agriculture, Berkeley, California, stationed at Fresno, California.

Authors wish to acknowledge the assistance of Sandy Barnard, Bambi Jones, and George Mcllece. This paper reports on work supported in part by National Science Foundation Grants GB-41233X and BMS73-02027-A02 to the Grassland Biome, U.S. International Biological Program, for "Analysis of Structure. Function and Utilization of Grassland Ecosystems."

Manuscript received June 18, 1978 portions of the US/IBP site, refrigerated and air-freighted to Dr. J.D. Smolik. Plant Science Department, South Dakota State University, Brookings. Nematodes were extracted by the Christie-Perry (1951) method, and a correction of $73 \%$ for extraction efficiency was used. Results of this preliminary effort indicated nematodes could be important components in the functioning of the annual grassland ecosystem. Numbers of nematodes were considerably higher in the May sample than in March on the ungrazed area, with an average of 5 to $12 \times$ $10^{6} / \mathrm{m}^{2}$ to a depth of $60 \mathrm{~cm}$ for the two dates. ${ }^{1}$ Biomass varied from about 623 to $1,309 \mathrm{mg} / \mathrm{m}^{2}$ (dry weight).

This limited study was conducted in 1976 to further investigate the importance of nematodes in a grazed and ungrazed annual grassland ecosystem. Importance in an ecosystem is often determined by measuring parameters such as nematode density and biomass at different seasons and making estimates of nematode metabolism and productivity.

\section{Study Area}

The San Joaquin Experimental Range is representative of the granitic soil area in lower foothill annual grasslands in central California. The area is the annual plant-oak woodland type, with scattered trees and brush. The herbaceous vegetation is made up almost entirely of annual plants. The nematode study area was within the US/IBP site, which is an open grassland area. The study area for nematode investigations was a uniform area of Ahwahnee coarse, sandy loam soil, moderately deep, on a $10 \%$ slope with northern exposure. The site was the open rolling slope described by Bentley and Talbot (1951), which is intermediate in herbage production between the swale or gentle slope sites and the rocky, steep slope sites comprising most of the area on the Experimental Range. Yearlong grazing by cows and calves constituted the grazed treatment, which was separated from the ungrazed area by a barbed wire fence (Fig. 1). The ungrazed area had not been grazed since 1971.

\section{Methods}

Two plots of 1 square foot $\left(30.48 \mathrm{~cm}^{2}\right)$ each in the grazed and the ungrazed areas were selected at random for each of five sampling dates from January 21 to May 24, 1976. The annual vegetation in these plots during this period ranged from early vegetative in January to mature stages in May. Aboveground biomass was determined by clipping the vegetation to ground level for both grazed and ungrazed plots inside a square-foot frame at each sampling period. Current year vegetation was placed in a labeled paper bag, oven dried at $60^{\circ} \mathrm{C}$, and total dry weight determined. The vegetation was then sorted into species and groups: Bromus mollis, B. diandrus, Vulpia megalura, Erodium spp. Trifolium spp., Lotus purshianus miscellaneous legumes, and miscellaneous forbs other than legumes. Litter from the prior years' growth

${ }^{1}$ Smolik, J.D. 1975. Unpublished results. 
February, when it was over $12 \%$ at the $0-10 \mathrm{~cm}$ depth and approximately $10 \%$ at lower depths. The soil was relatively dry on all subsequent dates (Fig. 2) and was less than $1 \%$ water at the $0-10 \mathrm{~cm}$ depth on the final sampling date in May.

Soil temperatures, expressed as a mean of temperatures at all depth increments, were always 1 to $2^{\circ} \mathrm{C}$ higher on grazed area (Fig. 2). Seldom was there more than $1^{\circ}$ difference between the $0-10$ and $50-60 \mathrm{~cm}$ core segments in either treatment during the morning sampling periods. The largest difference between the top and bottom segments was on May 25, when the soil temperatures in the ungrazed area were $26.5^{\circ} \mathrm{C}$, respectively in the grazed area.

Table 3. Nematode density and biomass in grazed and ungrazed grassland at 0-60 cm depth at San Joaquin Experimental Range, 1976. ${ }^{1}$

\begin{tabular}{|c|c|c|c|c|}
\hline \multirow[b]{2}{*}{ Sample date } & \multicolumn{2}{|c|}{$\begin{array}{c}\text { Nematode density } \\
\left(\times 10^{6} / \mathrm{m}^{2}\right)\end{array}$} & \multicolumn{2}{|c|}{$\begin{array}{l}\text { Biomass } \\
\left(\mathrm{mg} / \mathrm{m}^{2}\right)\end{array}$} \\
\hline & Grazed & Ungrazed & Grazed & Ungrazed \\
\hline February & 0.94 & 1.82 & 38.3 & 72.0 \\
\hline March & 4.19 & 3.13 & 175.4 & 125.9 \\
\hline April & 4.81 & 3.85 & 193.4 & 152.9 \\
\hline May & 2.82 & 1.99 & 112.8 & 79.3 \\
\hline Mean & 3.19 & 2.69 & 130.0 & 107.5 \\
\hline
\end{tabular}

${ }^{1}$ Corrected for extraction efficiency.

Total nematode density and biomass were highest on the grazed plot (Table 3, Fig. 2) at all sampling periods but February. The mean number of nematodes for the four sampling periods, corrected for extraction efficiency, was $3.2 \times 10^{6} / \mathrm{m}^{2}$ at $0-60 \mathrm{~cm}$ depth in the grazed plot and $2.7 \times 10^{6} / \mathrm{m}^{2}$ at $0-60 \mathrm{~cm}$ depth in the ungrazed plot. Nematode biomass was $130 \mathrm{mg} / \mathrm{m}^{2}$ and $108 \mathrm{mg} / \mathrm{m}^{2}$ at $0-60 \mathrm{~cm}$ on the grazed and ungrazed plots, respectively, and was at maximum in April on both plots. Nematode density was closely related to soil temperature and moisture and decreased with depth (Fig. 3). In February, when soil temperatures were low and soil moisture high, nematode density on both plots was low. As soil temperatures became
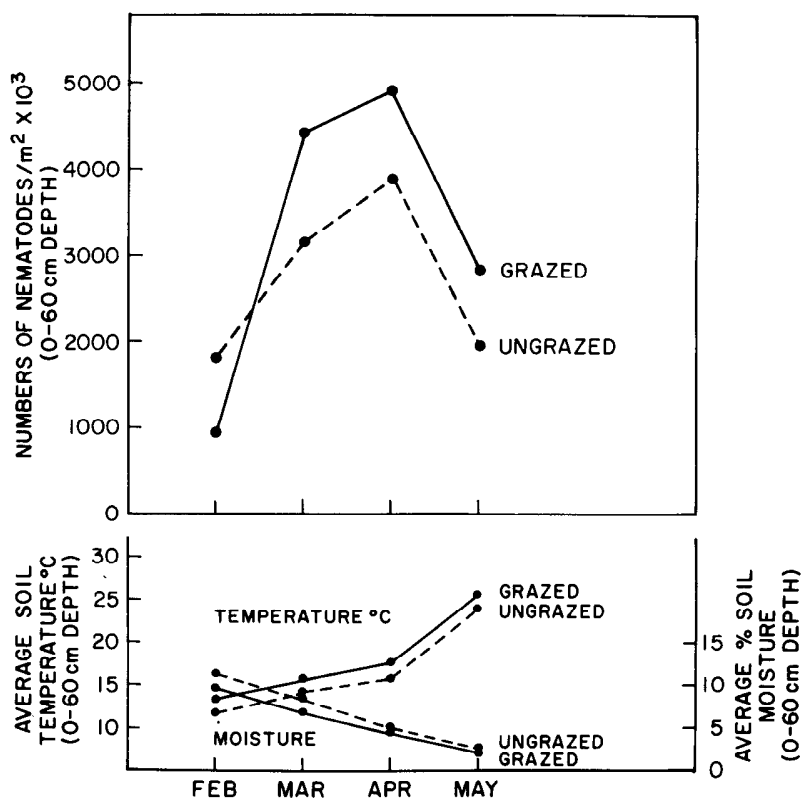

Fig. 2. Total nematode numbers and soil moisture and temperature in grazed and ungrazed grassland at the San Joaquin Experimental Range, California, 1976.

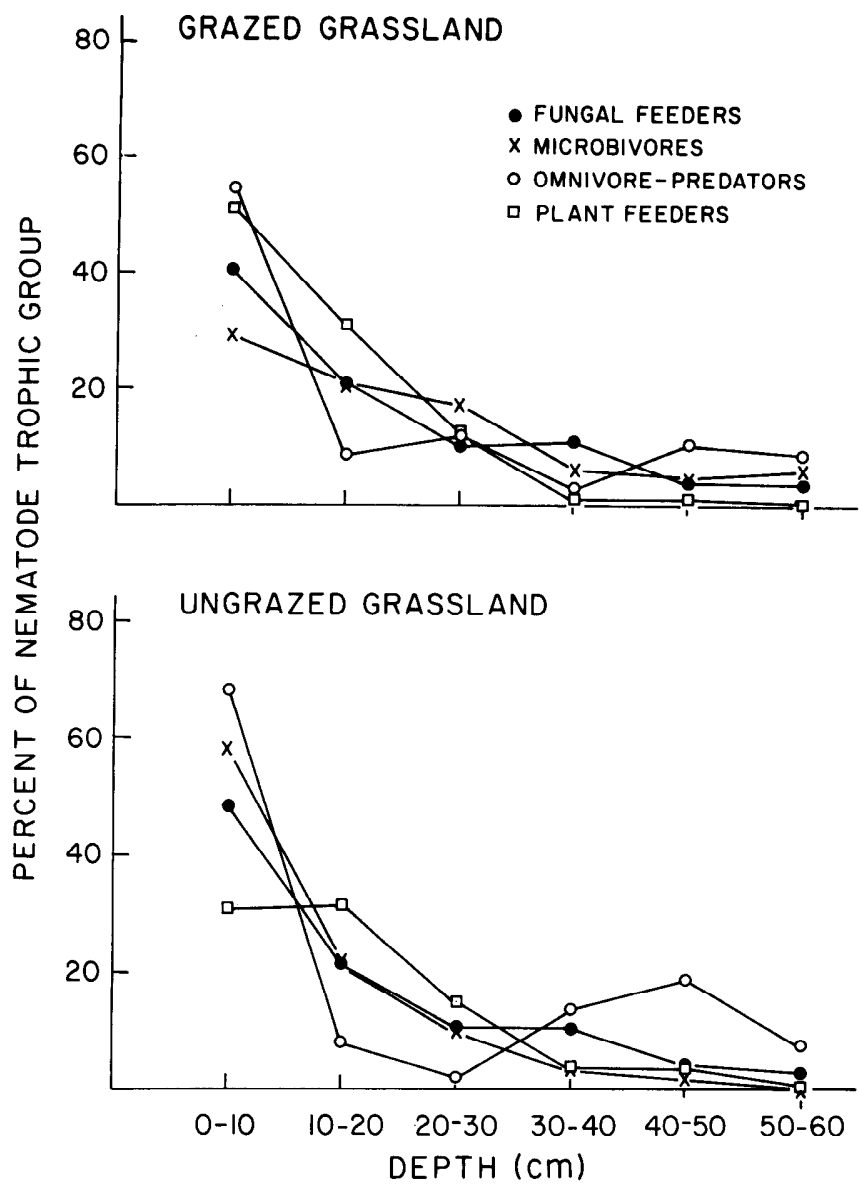

Fig. 3. Vertical distribution of nematode trophic groups on grazed and ungrazed grassland at the San Joaquin Experimental Range, California, 1976.

warmer and moisture levels declined to $4 \%$ to $5 \%$ in March and April, there was an increase in numbers of nematodes. Maximum nematode metabolism, production, and energy turnover probably occurred during this period when the range of soil moisture and temperature was more optimal for nematode activity. Nematode activity and density may have been minimal in May because some nematodes are known to enter an inactive state of cryptobiosis, which is brought about by unfavorable environmental conditions such as low soil moistures. Freckman (1978), working in desert soils, found the nematode community to be cryptobiotic when soil moisture was below $2.7 \%$, and it is possible similar conditions occurred during this study. Cryptobiosis enables nematodes to survive until favorable conditions of moisture and temperature return.

A comparison of this more comprehensive study with the 1974 survey shows a reversal in numbers of nematodes on grazed and ungrazed sites. In March, 1974, there was a greater number $\left(7.35 \times 10^{6} / \mathrm{m}^{2}, 0-60 \mathrm{~cm}\right.$ depth) and biomass $(0.918$ $\mathrm{g} / \mathrm{m}^{2}, 0-60 \mathrm{~cm}$ depth) of nematodes in the ungrazed grassland. Results of the March 1976 sampling indicated a greater nematode density $\left(4.19 \times 10^{6} / \mathrm{m}^{2}, 0-60 \mathrm{~cm}\right.$ depth) and biomass $\left(0.175 \mathrm{~g} / \mathrm{m}^{2}, 0-60 \mathrm{~cm}\right.$ depth) on the grazed grassland. The trophic structure of the March, 1974, ungrazed and grazed area was respectively 80 and $60 \%$ saprovores, whereas in March, 1976, fungivores and microbivores represented the nematode community in the ungrazed area by 33 and $36 \%$ and in the grazed area by 49 and $26 \%$, respectively (Table 4 ). Nematodes in all trophic groups were most abundant at the $0-10 \mathrm{~cm}$ depth, and numbers declined with increasing depth on both grazed and 
Table 4. Monthly numbers and biomass of nematode trophic groups corrected for extraction efficiency in grazed and ungrazed grassland at San Joaquin Experimental Range, 1976.

\begin{tabular}{|c|c|c|c|c|}
\hline \multirow[b]{2}{*}{ trophic groups } & \multicolumn{2}{|c|}{ Number $\times 10^{6} / \mathrm{m}^{2}$} & \multicolumn{2}{|c|}{ Biomass $\left(\mathrm{mg} / \mathrm{m}^{2}\right)$} \\
\hline & Grazed & Ungrazed & Grazed & Ungrazed \\
\hline \multicolumn{5}{|l|}{ Fungivores } \\
\hline February & 0.37 & 0.75 & 14.6 & 28.3 \\
\hline March & 2.04 & 1.03 & 81.7 & 41.1 \\
\hline April & 0.67 & 1.10 & 27.1 & 43.7 \\
\hline May & 1.16 & 0.53 & 46.3 & 21.1 \\
\hline Total & 4.24 & 3.41 & & \\
\hline \multicolumn{5}{|l|}{ Microbivores } \\
\hline February & 0.15 & 0.52 & 6.1 & 20.5 \\
\hline March & 1.08 & 1.12 & 43.4 & 44.6 \\
\hline April & 0.48 & 0.85 & 19.3 & 33.8 \\
\hline May & 0.99 & 0.94 & 39.7 & 37.8 \\
\hline Total & 2.70 & 3.43 & & \\
\hline \multicolumn{5}{|c|}{ Omnivore-predators } \\
\hline February & 0.15 & 0.12 & 6.4 & 5.1 \\
\hline March & 0.74 & 0.12 & 29.4 & 5.3 \\
\hline April & 0.09 & 0.25 & 3.6 & 9.7 \\
\hline May & 0.26 & 0.26 & 10.1 & 10.1 \\
\hline Total & 1.24 & 0.75 & & \\
\hline \multicolumn{5}{|l|}{ Plant parasites } \\
\hline February & 0.18 & 0.31 & 7.1 & 12.7 \\
\hline March & 0.31 & 0.53 & 12.6 & 21.5 \\
\hline April & 0.12 & 0.10 & 5.3 & 3.7 \\
\hline May & 0.30 & 0.19 & 11.9 & 7.4 \\
\hline Total & 0.91 & 1.13 & & \\
\hline \multicolumn{5}{|l|}{ Unidentifiable } \\
\hline February & 0.09 & 0.12 & 4.0 & 5.3 \\
\hline March & 0.02 & 0.33 & 8.2 & 13.4 \\
\hline April $^{1}$ & 3.45 & 1.55 & 138.1 & 62.0 \\
\hline May & 0.12 & 0.07 & 4.8 & 2.9 \\
\hline
\end{tabular}

${ }^{1}$ Ninety-five percent of all April data represents nematodes from $0-10 \mathrm{~cm}$ depth which were damaged when the refrigerator malfunctioned.

ungrazed areas (Fig. 3). Omnivore-predators were the most numerous trophic groups at the $0-10 \mathrm{~cm}$ and $40-50 \mathrm{~cm}$ depths. The percentage of plant feeders was greater at the $0-10 \mathrm{~cm}$ depth $(52 \%)$ on the grazed plot than on the ungrazed plot $(32 \%)$ and at the $10-20 \mathrm{~cm}$ depth on both plots; plant feeders were the most abundant trophic group.

On the basis of this study and the 1974 study, it would appear that the interaction of soil moisture and temperature appears to be a more important factor controlling the nematode populations and trophic structure than grazing. For example, the 1974 data were taken in a year of abundant rainfall, and soil moisture was not a limiting factor. Total numbers of nematodes were much greater in the March sampling in 1974 than in 1976 on both grazed and ungrazed plots. The highest nematode density in 1974 occurred on the ungrazed areas, where higher organic debris and soil microfloral activity probably provided a greater abundance and quality of food sources for the fungivorous and microbivorous nematodes. However, in 1976, although low soil moisture $( \pm 2.5 \%)$ limited total nematode density later in April and May, soil in the $0-10 \mathrm{~cm}$ depth grazed area was always several degrees warmer $\left(28.5^{\circ} \mathrm{C}\right)$ than the ungrazed soil $\left(26.5^{\circ} \mathrm{C}\right)$ (Fig. 2). A temperature optimal for nematode activity and reproduction was reached much sooner in the grazed area in March when moisture was not limiting than in the ungrazed area. This may explain why the numbers and biomass were higher in the grazed area than in the ungrazed area in 1976.

Evidence from two previous studies on the importance of nematodes on grazed and ungrazed grasslands have been inconclusive. Smolik (1974) found a greater nematode biomass on ungrazed pastures and Smolik and Rogers (1976) found no differences in nematode density and biomass between grazed, ungrazed, and burned shrub-steppe areas. This San Joaquin study further indicates that grazed or ungrazed grasslands are not the sole determinants of nematode density and biomass. Other factors influencing the nematode community appear to be abiotic (i.e., soil moisture and temperature).

Grazing may influence nematode populations indirectly by causing a shift in plant vegetation. For example, in 1974. grasses were predominant with $70 \%$ grass on the grazed plot and $88 \%$ grass on the ungrazed plot. By March, 1976, the grazed area consisted of only $19.5 \%$ grass, whereas the ungrazed area was $100 \%$ grass (Table 2). Forbs were the predominant vegetation in the grazed area. Other differences in nematode density between the 1974 and 1976 plant growing seasons at the San Joaquin site could be in part due to extraction methods, extraction efficiencies, and taxonomic and trophic groupings.

\section{Conclusions}

Results of this study, although of an exploratory nature and obtained in a season of unusually low rainfall, indicate soil-dwelling nematodes are an important component in the annual grassland ecosystem and deserve further, more detailed study, particularly on different sites with different soils and vegetation. In comparison, soil microarthropod biomass ranged from $53-22 \mathrm{mg} / \mathrm{m}^{2}$ for $0-10 \mathrm{~cm}$ depth samples taken in April and May, $1973^{2}$. This was lower than the nematode biomass of $117-40 \mathrm{mg} / \mathrm{m}^{2}$ for a similar depth in April and May, 1976. Smolik's (1974) South Dakota studies showed more nematodes on grazed rangelands, while a Washington study (Smolik and Rogers 1976) revealed little difference between grazed and ungrazed areas. These 1976 California tests indicated more nematodes on a grazed area where the vegetation was mostly forbs than on an adjacent ungrazed area with almost exclusively grass vegetation. Nematode community structure varied with fungivores $>$ microbivores $>$ omnivore-predators $>$ phytophages in the grazed grassland and microbivores $=$ fungivores $>$ phytophages $>$ omnivore-predators for the ungrazed grassland.

Nematode numbers and biomass in 1976 were much lower than found in preliminary tests in 1974 , when more than twice as much rainfall fell in the months of March and April. However, relative seasonal nematode densities were very similar to the usual seasonal pattern for aboveground live plant biomass of the annual plants at the San Joaquin site. Nematode numbers were low in winter when soil temperatures were low, even with relatively abundant soil moisture. Numbers rose and peaked in April with rising soil temperatures and intermediate soil moisture supplies. As temperatures rose more and soil moisture rapidly declined in May, nematode numbers dropped.

\section{Literature Cited}

Andrassy, I. 1956. The determination of volume and weight of nematodes. Acta. Zool. Acad. Sci. Hung. 2:1-15.

Bentley, J.R., and M.W. Talbot. 1951. Efficient use of annual plants on cattle ranges in the California foothills. U.S. Dep. Agr. Circ. No. 870. 52 p.

Christie, J.R., and V.G. Perry. 1951. Removing nematodes from soil. Proc. Helminthol. Soc. Wash. 18:106-108.

Duncan, D.A. 1975. The San Joaquin site of the Grassland Biome: Its relation to annual grassland ecosystem synthesis, p. 9-15. In: The California Annual Grassland Ecosystem: Symp. Proc. Amer. Soc. Agron., Anaheim, Calif., Jan. 30, 1975. Inst. Ecol., Univ. Calif., Davis.

${ }^{2}$ Burdick. D.J. 1979. Unpublished results. 
Freckman, Diana W. 1978. Ecology of anhydrobiotic soil nematodes. p. 345357. In: Crowe and Clegg (eds.) Dried biological systems. Academic Press. Inc.

Schmitt, D.P. 1973. Population fluctuations of some plant parasitic nematodes in the Kalso Prairie, lowa. Proc. Iowa Acad. Sci. 80:69-71.

Schmitt, D.P., and D.C. Norton. 1972. Relationships of plant parasitic nematodes to sites in native Iowa prairies. J. Nematol. 4:200-206.

Smolik, J.D. 1974. Nematode studies at the Cottonwood Site. US/IBP Grassland Biome Tech. Rep. No. 251. Colorado State Univ., Fort Collins. 80 p. Smolik, J.D., and L.E. Rogers. 1976. Effects of cattle grazing and wildfire on
soil-dwelling nematodes of the shrub-steppe ecosystem. J. Range Manage. 29:304-306.

Stanton, N.L. 1974. Soil organisms of Thunder Basin Grassland. AtlanticRichfield Co. Environmental Impact Analysis, Univ. Wyoming, Laramie. Yeates, G.W. 1974. Studies on a climosequence of soils in tussock grasslands. No. 2. Nematodes. N.Z.J. Zool. 1:171-177.

Yuen, P.H. 1966. The nematode fauna of the regenerated woodland and grassland of Broadbalk Wilderness. Nematologica 12:195-214. 